\title{
PERLINDUNGAN HUKUM KORBAN KECELAKAAN PENERBANGAN DALAM MEMPEROLEH GANTI RUGI
}

\author{
Muhammad Usman Syahirul Azmani \\ Program Magister Ilmu Hukum \\ Pascasarjana Fakultas Hukum Universitas Islam Malang \\ Jalan Mayjen Haryono No. 139 Malang \\ Email: usman.syahir@gmail.com
}

\begin{abstract}
Abstrak
Dalam setiap kegiatan penyelenggaraan penerbangan akan memiliki risiko munculnya kerugian akibat cacat produk. Penumpang sebagai Konsumen yang menderita kerugian dalam kecelakaan pesawat udara akibat cacat produk dapat menuntut ganti kerugian terhadap pihak yang dianggap bertanggungjawab. Penyelesaian ganti kerugian terhadap penumpang yang meninggal dunia, lukaluka atau cacat akibat kecelakaan pesawat udara tersebut sebagai salah satu tanggungjawab hukum dalam penyelenggara penerbangan. Namun persoalan penyelesaian ganti kerugian yang berkaitan dengan tanggungjawab produk (Product Liability) dalam penyelenggaraan penerbangan ini pada praktek seringkali belum sepenuhnya dapat diselesaikan, karena peraturan perundangundangan yang ada masih belum mengaturnya, baik hukum nasional maupun aturan hukum internasional.

Kata Kunci: kecelakaan penerbangan, prinsip-prinsip tanggungjawab, korban, perlindungan, hukum dan ganti rugi.

\section{Abstract}

In each flight management activity, there is a risk of loss due to product defects. Passengers as Consumers who suffer losses in airplane accidents due to product defects can claim compensation for those who are considered responsible. Completion of compensation for passengers who have died, injuries or defects caused by aircraft accidents is one of the legal responsibilities in the flight operator. However, the problem of settlement of compensation related to product liability in the administration of this flight in practice is often not completely resolved, because the existing laws and regulations still do not regulate it, both national law and international law.

Keywords: aviation accidents, principles of responsibility, victims, protection, law and compensation.

\section{PENDAHULUAN}

Perkembangan jumlah perusahaan penerbangan di satu sisi menguntungkan bagi para pengguna jasa transporatsi udara (penumpang dan pemilik kargo) karena akan banyak pilihan. Perusahaan-perusahaan tersebut bersaing untuk untuk menarik penumpang sebanyak-banyaknya dengan menawarkan tarif yang lebih murah atau menawarkan berbagai bonus. Namun di sisi lain, dengan tarif yang murah tersebut sering menurunkan kualitas pelayanan (service), bahkan yang lebih mengkhawatirkan lagi adalah akan menyebabkan berkurangnya kualitas pemeliharaan (maintenance) pesawat sehingga rawan terhadap keselamatan penerbangan dan akan berdampak kurang baik terhadap keamanan, kenyamanan dan perlindungan konsumen. Dalam dunia penerbangan dikenal dua pengertian
\end{abstract}


yakni kejadian (incident), dan Kecelakaan (accident). Kecelakaan adalah suatu peristiwa di luar keberangkatan ke bandar udara tujuan, di mana terjadi kematian atau luka parah atau kerugian yang disebabkan oleh benturan dengan pesawat udara atau semburan mesin jet pesawat udara atau terjadi kerusakan struktural atau adanya peralatan yang perlu diganti atau pesawat udara hilang sama sekali.sedangkan kejadian (incident), adalah peristiwa yang terjadi selama penerbangan berlangsung yang berhubungan dengan operasi pesawat udara yang dapat membahayakan terhadap keselamatan penerbangan. ${ }^{1}$

Kecelakaan- kecelakaan pesawat udara tersebut, dapat disebabkan berbagai faktor, antara lain faktor manusia (human), mesin pesawat udara (machine technical), dan cuaca (weather) ${ }^{2}$. Dari ketiga faktor tersebut, studi menunjukkan bahwa sekitar 55\% kecelakaan pesawat udara karena kesalahan/ kelalaian kapten penerbang sebagai penyebab kecelakaan, sedangkan $45 \%$ sisanya disebabkan oleh hal lain yang mendukung terjadinya kesalahan/ kelalaian kapten penerbang tersebut. Studi ini juga menunjukkan bahwa peran manusia ternyata sebagai faktor rutin yang sering menyebabkan terjadinya kecelakaan pesawat. ${ }^{3}$

Sebagaimana diketahui, Pesawat Lion Air JT 610 tujuan JakartaPangkalpinang pada 29 oktober 2018 lalu jatuh di perairan Karawang, dalam kecelakaan itu, sebanyak 189 penumpang dinyatakan seluruhnya tewas. KNKT memaparkan kronologi jatuhnya pesawat Lion Air PK-LQP melalui pembacaan sebagian data pada kotak hitam atau blackbox. Ketua KNKT Soerjanto Tjahjono menyebutkan, data yang ia dapatkan memperlihatkan pesawat mengalami stall atau kehilangan daya angkat sehingga terjatuh ${ }^{4}$. Maskapai penerbangan Lion Air memastikan akan memberikan santunan dan uang tunggu serta uang duka kepada ahli waris korban jatuhnya Pesawat Lion Air di tanjung karawang sebesar Rp 5.000.000, uang kedukaan Rp 25.000.000, serta uang santunan meninggal dunia sesuai Peraturan Menteri Perhubungan Nomor 77 Tahun 2011, yaitu sebesar Rp 1,25 miliar. $^{5}$

Sebenarnya, dikatakan Indonesia sudah meratifikasi peraturan penerbangan sesuai Konvensi Montreal 1999 pada 2017. Dalam peraturan ini, korban meninggal dunia mendapat nilai santunan lebih dari Rp 2 miliar. Namun besaran santunan Rp 2 miliar hanya berlaku untuk penerbangan rute luar negeri, bukan domestik. Sehingga santunan bagi para korban jatuhnya Lion Air JT-610 mengacu pada PM 77 Tahun 2011. Tidak hanya itu, santunan kepada para korban juga akan diberikan oleh PT Jasa Raharja (Persero) yang mendapat mandat menjamin setiap perjalanan moda transportasi umum, bahwa berdasarkan UU No 33 dan PMK No.

\footnotetext{
${ }^{1}$ H.K. Martono, Kecelakaan Pesawat Udara, Jakarta, Seputar Indonesia 2007, 5 Januari, Hal. 7

2 Ibid hal 12

${ }^{3}$ London, Jack W. 'General aviation crash course: The First 15 Days", 39 Trial Lawyers of America 56, 2003, Hal.2

${ }^{4}$ Tribunnews.com, 28 November 2018 Berita Terbaru Lion Air PK-LQP JT 610, Hasil Investigasi KNKT Data Black Box, Penyebab Pesawat Jatuh

${ }_{5}$ Nurmayanti. Liputan6.com, 1 November 2018, Rincian Santunan yang Diberikan Lion Air ke Ahli Waris Korban Pesawat Jatuh
} 
15 tahun 2017, bagi korban meninggal dunia, Jasa Raharja siap menyerahkan hak santunan sebesar Rp 50 juta. $^{6}$

Dana santunan atau kompensasi yang diberikan kepada keluarga korban tewas kecelakaan penerbangan merupakan kewajiban dari pihak maskapai dan pihak terkait akibat adanya kecelakaan tersebut berdasarkan Peraturan Menteri Perhubungan Nomor 77 Tahun 2011, selain itu pemberian kompensasi tersebut tidak menggugurkan hak korban maupun ahli warisnya untuk menggugat, kewajiban atau tanggungjawab para pihak menjadi tidak terbatas jika kecelakaan disebabkan karena Human Error.

Selain itu dalam setiap kegiatan penyelenggaraan penerbangan akan memiliki risiko munculnya kerugian akibat cacat produk, yang kemudian berdampak pada konsekuensi hukum. Resiko tersebut berkaitan dengan penyelesaiaan ganti kerugian kepada penumpang sebagai bentuk tanggungjawab hukum (legal liability) perusahaan sebagai produsen. Resiko kerugian yang ditanggung produsen pesawat udara ini berkaitan dengan tanggungjawab produknya, yang kemudian resiko itu dialihkan kepada perusahaan asuransi sebagai penanggung sesuai dengan nilai jaminan yang dipertanggungkan dengan meneria pembayaran sejumlah uang premi dari produsen pesawat udara (third party insurance). Penumpang sebagai Konsumen yang menderita kerugian dalam kecelakaan pesawat udara akibat cacat produk dapat menuntut ganti kerugian terhadap pihak yang dianggap bertanggungjawab. Penyelesaian ganti kerugian terhadap penumpang yang meninggal dunia, luka-luka atau cacat akibat kecelakaan pesawat udara tersebut sebagai salah satu tanggungjawab hukum dalam penyelenggara penerbangan. ${ }^{7}$

Namun persoalan penyelesaian ganti kerugian yang berkaitan dengan tanggungjawab produk (Product Liability) dalam penyelenggaraan penerbangan ini pada praktek seringkali belum sepenuhnya dapat diselesaikan, karena peraturan perundang-undangan yang ada masih belum mengaturnya, baik hukum nasional maupun aturan hukum internasional. Disamping itu kasus serupa juga pernah terjadi pada tahun 2009 ketika sekelompok korban dan ahli waris korban meninggal kecelakaan jatuhnya pesawat Mandala Air, yang sejumlah 33 orang bersama kuasa hukumnya bersama-sama menggugat Maskapai, Perusahaan Produksi pesawat, dan perusahaan pendesain pesawat yang tertulis dalam Putusan Pengadilan Negeri Jakarta Pusat Nomor :186/PDT.G/2009/PN.JKT.PST. Dalam putusan tersebut hakim menolak gugatan para penggugat untuk seluruhnya dengan salah satu pertimbangan "menurut majelis hakim dan demi kepastian hukum bahwa penggugat secara hukum tidak memiliki hak hukum untuk menerima kompensasi atau santunan apapun lagi karena para penggugat telah secara tegas menandatangani surat pernyataan pelepasan hak/ Release and

${ }^{6}$ Op, Cit

${ }^{7}$ David T. Norton, Crisis Management Planning for Small Air Carrier Aircraft Paris Manufacturers, Installers or Maintainers, and Other Aviation Industri Participants, 66 Journal of Air Law Commerce, Springs: Southern Methodist University School of Law, 2001, pages 543-546. 
Discharge $(R \& D)$ dan melepaskan haknya untuk mengajukan gugatan terhadap Tergugat." 8

Selain itu aturan hukum nasional yang mengatur tentang kompensasi yang diberikan akibat kerugian masih menjadi polemik, karena besarnya kompensasi dianggap tidak sebanding dengan kerugian terhadap nyawa, ukuran tentang apa yang menjadi dasar pemberian ganti kerugian dalam perbuatan melawan hukum yang mengakibatkan korban jiwa juga sulit ditentukan. Perbuatan melawan hukum terhadap tubuh dan jiwa manusia pada dasarnya telah diatur di dalam Pasal 1370 Kitab Undang-Undang Hukum Perdata. Apabila perbuatan tersebut mengakibatkan korban meninggal dunia maka terdapat hak bagi ahli waris untuk menuntut ganti rugi. Namun, hak atas ganti rugi yang telah diakomodir ini sayangnya tidak dapat dijelaskan ukurannya karena pasal ini berpatokan pada ahli waris yang sewajarnya mendapatkan nafkah dari korban., ada ketidakpuasan terhadap aturan hukum indonesia oleh keluarga korban, sehingga setelah sebagian keluarga korban mendapat kompensasi dari maskapai penerbangan dan asuransi, masih banyak keluarga korban yang tidak mengambil kompensasi/ dana santunan kepada maskapai, tetapi melakukan upaya hukum penuntutan terhadap perusahaan produsen pesawat yang berada di luar negeri untuk mendapatkan kompensasi yang lebih besar.

Berdasarkan latar belakang tersebut diatas, masalah yang akan diangkat penulis adalah:

1. Bagaimana perlindungan terhadap korban kecelakaan penerbangan untuk mendapatkan ganti rugi?

2. Upaya hukum apa yang dapat dilakukan oleh korban kecelakaan penerbangan?

\section{METODE PENELITIAN}

Dalam penelitian ini penulis menggunakan penelitian hukum normatif, asasasas hukum yaitu penelitian yang difokuskan untuk mengkaji penerapan kaidahkaidah atau norma-norma dalam hukum positif.9 Adapun penelitian hukum normatif mencakup penelitian terhadap sistematika hukum, penelitian terhadap taraf sinkronisasi hukum, penelitian sejarah hukum dan penelitian perbandingan hukum. ${ }^{10}$

Dalam penelitian normatif ini menggunakan pendekatan perundangundangan (statute approach) dan pendekatan kasus (case approach) yang didukung dengan bahan hukum primer berupa peraturan perundang-undangan yang berlaku dan bahan hukum sekunder berupa buku-buku hukum yang relevan dengan isu hukum serta bersifat deskriptif analitis

Sumber bahan yang digunakan dalam penelitian ini adalah bahan yang bersumber dari perundang-undangan atau dari bahan hukum, baik itu bahan hukum primer, bahan hukum sekunder dan bahan hukum tersier.

\footnotetext{
${ }^{8}$ Putusan Pengadilan Negeri Jakarta Pusat Nomor :186/PDT.G/2009/PN.JKT.PST., Hal. 176-177

${ }^{9}$ Ibrahim Jhonny, Teori dan Metodologi Penelitian Hukum Normatif, Malang : PT. Bayu Media Publishing, 2010, hlm.295

${ }^{10}$ Soerjono Soekanto, Pengantar Penelitian Hukum, Jakarta, UI Press, 2000 hlm. 51
} 


\section{PEMBAHASAN}

\section{Perlindungan Hukum Terhadap Korban Kecelakaan Penerbangan Dalam Memperoleh Ganti Rugi}

Indonesia telah meratifikasi Convention for the Unification of Certain Rules

for International Carriage by Air (Konvensi Unifikasi Aturan-Aturan Tertentu tentang Angkutan Udara Internasional) yang telah ditetapkan pada tanggal 28 Mei 1999 di Montreal, Kanada. Hasil ratifikasi tersebut menjadi aturan hukum nasional dalam bentuk Peraturan Presiden Nomor 95 Tahun 2016, akan tetapi perpres tersebut hanya berlaku untuk penerbangan internasional Berdasarkan atau rute luar negeri, sehingga dalam perlindungan hukum korban kecelakaan penerbangan nasional yang terbaru dan mengacu pada konvensi montreal masih berlaku ketentuan Peraturan Menteri Perhubungan Nomor 77 Tahun 2011.

konvensi montreal 1999 atau Perpres nomor 95 tahun 2016 maka besaran ganti rugi oleh korban penumpang. Adapun nilai terbaru tanggung jawab pengangkut sesuai dengan yang telah ditentukan dalam Konvensi Montreal 1999 adalah:

1. Jumlah kompensasi bagi penumpang yang meninggal atau menderita akibat kecelakaan pesawat udara sampai dengan 113.100 Special Drawing Rights (SDR) atau sekitar Rp 2,03 miliar sesuai dengan Pasal 21 ayat (1) Jika penumpang ingin mengajukan klaim melebihi batas 113.100 SDR tersebut, berlaku asas tanggung jawab berdasarkan unsur kesalahan (liability based on fault). Maskapai penerbangan harus membuktikan bahwa tidak ada kesalahan yang disengaja di pihaknya sesuai dengan Pasal 21 ayat (2)

2. Dalam hal kerugian yang diakibatkan oleh keterlambatan pesawat udara, maskapai penerbangan wajib memberikan kompensasi maksimum 4.694 SDR atau sekitar Rp. 84,2 juta sesuai dengan Pasal 22 ayat (1)

3. Untuk kehilangan, kerusakan, ataupun musnahnya barang bawaan dan bagasi, tanggung jawab pengangkut udara dibatasi sampai dengan maksimum 1.131 SDR atau sekitar Rp 20,3 juta sesuai dengan Pasal 22 ayat (2)

4. Untuk pengiriman kargo, pada kerusakan, kehilangan, keterlambatan, atau musnahnya kargo, pengirim berhak atas ganti rugi maksimum 19 SDR atau sekitar Rp 341 ribu per kilogram sesuai dengan Pasal 22 ayat (3)

1 SDR setara dengan sekitar 1,35 USD berdasarkan data IMF per tanggal 24 Januari 2017. Sedangkan kurs dollar AS rata-rata sebesar Rp13.300,- per tanggal 1 Februari 2017)

Berdasarkan Peraturan Menteri Perhubungan Nomor 77 Tahun 2011 tentang Tanggung Jawab Pengangkut Angkutan Udara Pasal 3, besarnya ganti kerugian terhadap penumpang yang meninggal dunia, cacat tetap atau luka-luka yaitu sebagai berikut :

- Penumpang yang meninggal dunia di dalam pesawat udara karena akibat kecelakaan pesawat udara atau kejadian yang semata-mata ada hubungannya dengan pengangkutan udara diberikan ganti kerugian sebesar Rp 1.250.000.000 (satu miliar dua ratus lima puluh juta rupiah) per penumpang. Pasal 3 bagian a

- Penumpang yang dinyatakan cacat tetap total oleh dokter dalam jangka 
waktu paling lambat 60 hari kerja sejak terjadinya kecelakaan diberikan ganti kerugian sebesar Rp 1.250.000.000 (satu miliar dua ratus lima puluh juta rupiah) per penumpang. Sedangkan untuk cacat sebagian diberikan ganti rugi maksimal 150 juta per penumpang

- Jumlah kompensasi bagi penumpang yang meninggal akibat kejadian yang ada hubungannya dengan pengangkutan udara saat meninggalkan ruang tunggu bandara menuju pesawat atau saat meninggalkan pesawat menuju ruang kedatangan bandara tujuan atau bandara transit adalah $\mathrm{Rp} 500$ juta sesuai dengan Pasal 3 ayat (b)

- Sedangkan pada pasal 3 bagian e, penumpang yang mengalami luka-luka dan harus menjalani perawatan di rumah sakit, klinik atau balai pengobatan sebagai pasien rawat inap atau rawat jalan, akan diberikan ganti kerugian sebesar biaya perawatan yang nyata paling banyak Rp. 200.000.000 (dua ratus juta rupiah) per penumpang.

- Untuk kehilangan, kerusakan, ataupun musnahnya barang bawaan dan bagasi setelah 14 hari kalender, maskapai harus memberikan kompensasi Rp 200.000,- per kg dan maksimal Rp 4 juta. Dalam masa menunggu tersebut, penumpang mendapat uang tunggu Rp 200.000,- per hari selama maksimal tiga hari sesuai dengan Pasal 5 ayat (1/), (2), (3)

- Untuk kerusakan kargo, pengirim mendapat kompensasi Rp 50.000,- per KG. sedangkan untuk kehilangan, atau musnahnya kargo, pengirim mendapat kompensasi Rp 100.000,- per kilogram sesuai dengan Pasal 7.

Selain itu korban penumpang Warga Negara Indonesia juga mendapatkan santunan dari perusahaan asuransi negara PT. Jasa Raharjda (Persero) berdasarkan PMK Nomor 15 tahun 2017 tentang Besar Santunan dan Iuran Wajib Dana Pertanggungan Wajib Kecelakaan Penumpang Alat Penumpang Angkutan umum di Darat, Sungai/ Danau, Feri/ Penyeberangan, Laut, dan Udara yang menyebutkan:

Pada pasal 4

(1) Penumpang yang menjadi korban akibat Kecelakaan selama berada di dalam Angkutan penumpang umum di udara atau ahli warisnya berhak atas Santunan.

(2) Besar Santunan sebagaimana dimaksud pada ayat (1) ditentukan sebagai berikut:

a. Ahli waris dari penumpang yang meninggal dunia berhak atas Santunan sebesar Rp50.000.000,00 (lima puluh ju ta rupiah).

b. Penumpang yang mengalami cacat tetap berhak atas Santunan yang dihitung berdasarkan angka persentase sebagaimana ditetapkan dalam Pasal 10 ayat (3) Peraturan Pemerintah Nomor 17 Tahun 1965 tentang Ketentuan-Ketentuan Pelaksanaan Dana Pertanggungan Wajib Kecelakaan Penumpang dari besar Santunan meninggal dunia sebagaimana dimaksud dalam huruf (a)

c. Penumpang yang memerlukan perawatan dan pengobatan berhak atas Santunan berupa: 1. penggantian biaya perawatan dan pengobatan dokter paling banyak Rp25.000.000,00 (dua puluh lima juta rupiah) 2. biaya ambulans atau kendaraan yang membawa penumpang ke fasilitas 
kesehatan paling banyak Rp500.000,00 (lima ratus ribu rupiah); dan/ atau 3. biaya pertolongan pertama pada Kecelakaan paling banyak Rpl.000.000,00 (satu juta rupiah).

Pasal 5 PMK Nomor 15 tahun 2017 menyebutkan dalam hal penumpang yang meninggal dunia akibat Kecelakaan selama berada di dalam alat Angkutan umum di darat, sungai/ danau, feri/ penyeberangan, laut, dan udara tidak mempunyai ahli waris, kepada pihak yang menyelenggarakan penguburan diberikan penggantian biaya penguburan sebesar $\mathrm{Rp}$ 4.000.000,00 (empat juta rupiah).

Kompensasi khusus juga diberikanUntuk korban kecelakaan penumpang Pegawai Negeri Sipil (PNS) Aparatur Sipil Negara (ASN) maupun calon PNS berdasarkan Peraturan Menteri Keuangan Nomor 208/PMK.02/ 2015 tentang Tata Cara Penyediaan, dan Pertanggungjawaban Dana Iuran Jaminan Kecelakaan Kerja dan Jaminan Kematian Bagi Aparatur Sipil Negara yang Bekerja pada Instansi Pemerintah Pusat. Kompensasi atau santunan tersebut diberikan kepada ahli waris korban ASN/ PNS melalui TASPEN dengan jumlah yang ditentukan perdasarkan metode penghitungan dari Permenkeu tersebut.

Peraturan Menteri Ketenagakerjaan Nomor 26 Tahun 2015 Untuk korban kecelakaan yang bekerja pada maskapai yang mengalami kecelakaan kerja, dalam hal ini pilot, co-pilot, pramugari dan kru lainnya yang meninggal akibat kecelakaan kerja akan mendapat santunan dari BPJS Ketenagakerjaan sejumlah 48 kali gaji yang dilaporkan perusahaan atau peserta BPJS tersebut. BPJSK juga memberikan beasiswa sejumlah RP. 12.000.000,- (dua belas juta rupiah) pada anak setiap kru maupun pilot yang tewas akibat kecelakaan kerja.

Semua jenis santunan yang penulis jelaskan di atas adalah santunan wajib yang harus diberikan kepada korban pengguna jasa angkutan udara berdasarkan sistem tanggungjawab mutlak (Strict liability) yang terdapat pada hukum positif yang ada di Indonesia, dalam kasus kecelakaan penerbangan nasional, maskapai wajib memberikan santunan kepada korban atau ahli waris korban tanpa disertai syarat-syarat yang memberatkan seperti perjanjian pelepasan hak untuk menuntut pihak maskapai maupun afiliasinya di kemudian hari/ atau perjanjian Research and Discharge $(R \& D)$ berdasarkan ketentuan Permenhub Nomor 77 tahun 2011. Untuk korban kecelakaan penerbangan rute antar negara/ luar negeri, berdasarkan pasal 21 Perpres nomor 95 tahun 2016, ganti rugi terhadap korban penumpang meninggal atau luka tidak melebihi SDR 100.000 atau 2,03 milyar rupiah. ${ }^{11}$, dan maskapai tidak bisa dimintai pertanggungjawaban lebih dari SDR 100.000 selama maskapai bisa membuktikan bahwa kecelakaan bukan disebabkan oleh kelalaian maupun perbuatan melawan hukum pihak maskapai maupun agen dan pekerjanya.

Perpres Nomor 95 Tahun 2016 juga menyebutkan bahwa perjanjian oleh pengangkut atau maskapai yang mengandung klausul batasan tanggungjawab atau pelepasan tanggungjawab, maka klausulnya saja yang tidak sah/ batal demi hukum.

Jika kecelakaan penerbangan terjadi akibat kesalahan pengangkut/

${ }^{11}$ Pasal 21 ayat (1) Peraturan Presiden Nomor 95 tahun 2016 tentang ratifikasi Montreal Convention 1999 
maskapai, maka pertanggungjawaban para pihak menjadi tidak terbatas, sistem Liability based on fault menjadi perlindungan hukum terhadap korban yang telah diatur dalam tiap Hukum positif di Indonesia, seperti KUHPerdata, UU perlindungan Konsumen, UU Penerbangan, Permenhub Nomor 77 tahun 2011 bahkan Perpres Nomor 95 tahun 2016 tentang ratifikasi Montreal Convention 1999. Ahli waris korban memiliki hak untuk menuntut lebih tinggi untuk kerugian materiil maupun imateriil kepada pihak maskapai.

Terkadang kecelakaan penerbangan terjadi bukan semata-mata kelalaian atau kesalahan maskapai, cacat produk terhadap pesawat yang diproduksi perusahaan produsen pesawat juga menjadi faktor terjadinya kecelakaan. Tanggungjawab produsen atas cacat produk dalam hukum perdata berlaku prinsip Liability based on fault. Pertanggungjawaban yang mensyaratkan adanya unsur kesalahan (fault liability) di Indonesia, pertanggungjawaban yang mensyaratkan adanya unsur kesalahan adalah perbuatan melawan hukum (PMH) Pasal 1365 KUHPerdata menjelaskan bahwa tiap perbuatan melanggar hukum, yang menyebabkan adanya kerugian kepada orang lain, mewajibkan orang karena salahnya, untuk mengganti kerugian tersebut. Akan tetapi belum ada aturan nasional maupun yang secara khusus mengatur ganti rugi kepada penumpang akibat cacat produk pesawat. Peraturan tentang kewajiban produsen belum menemukan arah yang implisit dalam konvensi internasional di bidang penerbangan serta Peraturan perundang-undangan penerbangan nasional. Dalam prakteknya, kewajiban produsen pesawat, karena produk cacat harus diselesaikan melalui proses litigasi dengan menerapkan prinsip kewajiban produk yang ketat.

\section{Upaya hukum yang dapat dilakukan oleh korban kecelakaan penerbangan dalam memperoleh ganti rugi}

Dalam hal kecelakaan penerbangan, selain besar santunan wajib yang harus diberikan oleh maskapai, korban maupun ahli warisnya dapat menuntut ganti rugi materiil maupun imateriil terhadap para maskapai, berdasarkan presumption of liability. Atau jika di-Indonesiakan lebih kurang berarti asas praduga bersalah."

Dengan konsep praduga bersalah tersebut, perusahaan penerbangan harus bertanggung jawab untuk memberikan ganti rugi kepada penumpang. Konsep ini, tambah Martono, membawa implikasi pada beban pembuktian di persidangan. Dalam konsep praduga bersalah ini, perusahaan penerbangan harus membuktikan bahwa dirinya tidak bersalah. 'Inilah yang dimaksud dengan pembuktian terbalik. Dijelaskan pula bahwa "tanggung jawab maskapai penerbangan dalam konsep ini terbatas. ${ }^{12}$ Namun, ceritanya akan berbeda jika korban atau ahli warisnya bisa membuktikan bahwa perusahaan penerbangan melakukan kesalahan dengan sengaja (wishful misconduct) maka tanggung jawab maskapai menjadi tidak terbatas alias unlimited liability. Hal ini menjadi hambatan dikarenakan hasil investigasi KNKT tidak bisa dijadikan bukti di persidangan, sebab investigasi KNKT bertujuan untuk mencari tahu penyebab

\footnotetext{
${ }^{12}$ https://www.hukumonline.com/klinik/detail/ulasan/lt4e6d82a093116/bagaimana-caramenuntut-ganti-kerugian-dari-maskapai-penerbangan- diakses tanggal 26 Juni 2019
} 
terjadinya kecelakaan, bukan mencari siap yang salah.

Baik aturan Perpres nomor 95 tahun 2016 maupun Permenhub nomor 77 tahun 2011 tidak membatasi tanggungjawab pengangkut udara/ maskapai dalam menyelesaikan sengketa, korban dalam menuntut ganti kerugian dapat menyelesaikan sengketa dengan maskapai melalui litigasi maupun non litigasi.

Upaya penyelesaian sengketa melalui non litigasi dapat menghemat biaya dibandingkan memalui litigasi, akan tetapi korban maupun kuasa hukumnya hanya akan melakukan penyelesaian sengketa melalui cara tersebut jika melihat adanya itikad baik yang dilakukan oleh pihak yang bertanggungjawab atas kecelakaan penerbangan.

Dalam kecelakaan penerbangan rute antar negara, berdasarkan aturan Montreal Convention 1999 yang telah diratifikasi menjadi Peraturan Presiden Nomor 95 tahun 2016, upaya penyelesaian sengketa atau tuntutan ganti rugi terhadap kematian, article 33 konvensi ini atau pasal 33 dalam perpres ini menjelaskan bahwa ahli waris korban dapat menuntut pertanggungjawaban melaui pengadilan berdasarkan yurisdiksi dimana perusahaan pengangkut berdomisili, di pengadilan mana domisili korban, di yurisdiksi mana kecelakaan pesawat terjadi, ataupun pengadilan mana perjanjian pengangkutan dilakukan. Sementara untuk sengketa atas kargo penumpang, pasal 34 Perpres nomor 95 tahun 2016 menyebutkan bahwa penyelesaian sengketa tersebut hanya bisa dilakukan melalui arbitrase.

Terhadap kecelakaan penerbangan rute dalam negeri, Peraturan Menteri Perhubungan Nomor 77 tahun 2011 tidak membatasi hak korban ataupun ahli warisnya dalam meminta ganti rugi, tanggungjawab maskapai bisa diselesaikan melaui jalur litigasi maupun non litigasi.

Tidak menutup kemungkinan jika kecelakaan disebabkan oleh cacat produk. maka korban berhak melakukan upaya penyelesaian sengketa melalui gugatan di pengadilan negara produsen pesawat berasal, oleh karena itu, bisa saja tuntutan dilakukan dengan mengikuti proses hukum Common Law, yang menganut yurisprudensi, dan karena produsen juga bertanggungjawab terhadap produk (product liability).

Dengan melalui upaya Hukum internasional, upaya ini dibagi menjadi hukum internasional publik, dan hukum perdata internasional. Sebagaimana penulis rangkum dalam buku Pengantar Hukum Internasional yang ditulis oleh Mochtar Kusumaatmadja dan Etty R. Agoes. hukum perdata internasional ialah keseluruhan kaidah dan asas hukum yang megatur hubungan perdata yang melintasi batas negara. Dengan perkataan lain, hukum yang mengatur hubungan hukum perdata antara para pelaku hukum yang masing-masing tunduk pada hukum perdata (nasional) yang belainan. ${ }^{13}$ yang membedakan hukum perdata internasional dengan hukum internasional publik terletak dalam sifat hukum hubungan atau persoalan yang diaturnya (objeknya). ${ }^{14}$

\footnotetext{
${ }^{13}$ Mochtar Kusumaatmadja dan Etty R. Agoes, Pengantar

Hukum Internasional, Bandung: PT. Alumni, 2003; hal 1-2 ${ }^{14}$ Ibid
} 
Gugatan yang ditujukan kepada produsen pesawat akan mengandung beberapa isu dalam hukum perdata internasional. Isu 'conflict of law' akan ditemukan karena penggugat berasal dari Negara yang berbeda dengan tempat pengadilan dimana kasus disidangkan. Pada prinsipnya siapapun berhak membawa kasusnya ke pengadilan di luar wilayah domisilinya (negara), termasuk bila kedudukan hukum tergugat berada di Negara yang berbeda dengan penggugat. Di Amerika Serikat, gugatan perdata oleh orang asing atas kelalaian atau kesalahan yang menimbulkan kerugian dapat dilakukan, gugatan ini sering disebut dengan transnational litigation.

Karena gugatan ini diajukan ke pengadilan di negara yang menganut sistem hukum common law, maka dalam prosesnya nanti pengadilan akan memeriksa perkara dengan menggunakan prinsip-prinsip conflict of law yang telah menjadi preseden. Hakim akan melihat putusan-putusan atau yurisprudensiyurisprudensi sebelumnya dalam kasus yang serupa. ${ }^{15}$

Setidaknya ada beberapa keuntungan dan hambatan yang dapat dihadapi oleh penggugat asing di pengadilan luar negeri.

Keuntungan pertama, nilai ganti rugi yang mungkin diperoleh di Pengadilan Amerika Serikat dapat lebih besar jumlahnya. Di pengadilan Amerika Serikat, penggugat dimungkinkan untuk menuntut ganti kerugian yang disebut dengan Punitive Damages. Ganti kerugian ini di luar dari kerugian materiil yang diderita penggugat. Bila dikabulkan, nilai ganti rugi Punitive Damages ini dapat lebih besar jumlahnya dibanding kerugian materiil itu sendiri.

Keuntungan kedua, pengadilan di Amerika Serikat telah memiliki pengalaman dalam menyelesaikan perkara-perkara ganti kerugian akibat kecelakaan pesawat, atau kelalaian perusahaan. Hakim-hakim telah memiliki pengalaman yang cukup dan preseden yang lengkap. Sehingga hasil akhir dari gugatan dapat lebih diprediksi. Namun penggugat asing juga harus menghadapi beberapa hambatan. ${ }^{16}$

Pertama, hambatan non-teknis. Penggugat tidak familiar dengan hukum di Amerika Serikat, oleh karena itu memerlukan penasihat hukum yang dapat dipercaya untuk mewakili kepentingan penggugat. Sedangkan mendapatkan penasihat hukum yang dapat dipercaya seringkali tidaklah mudah.

Kedua, hambatan teknis hukum. Sebelum pokok perkaranya diperiksa oleh hakim, penggugat seringkali harus menghadapi perlawanan dari tergugat. Di antara perlawanan yang paling sering adalah Forum non Coveniens ("FNC"). Perlawanan $F N C$ berarti tergugat mendalilkan bahwa pengadilan tidak tepat mengadili perkara ini karena ada pengadilan lain yang lebih sesuai (appropriate).

Perlawanan $F N C$ adalah perlawanan yang paling sering digunakan di pengadilan dengan sistem hukum common law. Hakim harus mempertimbangkan banyak hal, di antaranya kepentingan penggugat dan kepentingan publik. Untuk memutuskan perlawanan ini saja, dapat memakan waktu persidangan yang lama,

\footnotetext{
${ }^{15}$ Dimas Hutomo,

S.H.,https://www.hukumonline.com/klinik/detail/ulasan/lt5bf681e59f734/dasar-keluarga-korbankecelakaan-bisa-menggugat-produsen-pesawat/ diakses pada hari Kamis tanggal 22 November 2018 pukul 19.00

${ }^{16}$ Cornell law school,FNC, https://www.law.cornell.edu/wex/forum_non_conveniens
} 
termasuk proses banding sampai ke pengadilan tingkat tertinggi.

Dalam menggugat manufaktur pesawat berarti di luar konvensi-konvensi internasional tentang penerbangan, karena tidak ada konvensi yang mengatur mengenai hal itu.

Ada 3 faktor dalam hal seseorang menggugat manufaktur pesawat terbang:

1) Manufacture defect;

2) Design defect;

3) Failure to warn.

Terkait kasus gugatan keluarga korban kecelakaan maskapai Lion Air dengan pesawat Boeing 737 MAX yang ditujukan ke Boeing di AS, bisa disebabkan atas alasan ketiga di atas ketika Boeing mengeluarkan manual Automated stallprevention system untuk pesawatnya setelah kecelakaan JT610 yang dianggap baru bagi para pilotnya.

\section{PENUTUP}

Perlindungan Hukum terhadap Korban Kecelakaan Penerbangan dalam memperoleh ganti rugi, jika penerbangan tersebut adalah penerbangan internasional atau rute antar negara maka korban penumpang WNI berdasarkan Peraturan Presiden Nomor 95 tahun 2016 tentang Pengesahan Konvensi Unifukasi Aturan-Aturan Tertentu Tentang Angkutan Udara Internasional.

\section{DAFTAR PUSTAKA}

Abdulkadir Muhammad, Hukum Perjanjian, Citra Aditya Bakti, Jakarta,1986

Az.Nasution, Hukum Perlindungan Konsumen Suatu Pengantar, (Jakarta: Diadit Media, 2002)

Chairun Pasribu,Suharawardi Lubis, Hukum Perjanjian dalam Islam, Jakarta,

David T. Norton, Crisis Management Planning for Small Air Carrier Aircraft Paris Manufacturers, Installers or Maintainers, and Other Aviation Industri Participants, 66 Journal of Air Law Commerce, Springs: Southern Methodist University School of Law, 2001

E. Suherman, Aneka Masalah Hukum Kedirgantaraan, (Bandung: Mandar Maju, 2000)

E. Suherman, Hukum Udara Indonesia dan Internasional (kumpulan karangan), Alumni, Bandung, 1979,

Erman Rajagukguk, Agenda Pembaharuan Hukum Ekonomi di Indonesia Menyongsong Abad XXI, UNISIA No.33IXVIIII1I97, (1997)

Fadia Fitriyanti dan Sentot Yulianugroho,2007, Hukum Perniagaan Internasional, Lab Hukum Universitas Muhammadiyah Yogyakarta

H.K Martono \& Amad Sudiro, Hukum Udara Nasional dan Internasional Publik (Publik Internasional and National Air Law), Jakarta: Rajawali Press

Ibrahim Jhonny, Teori dan Metodologi Penelitian Hukum Normatif, Malang : PT. Bayu Media Publishing, 2010 
J. Russel Davis, American Law of Products Liability, (New York: The Lawyers Cooperative Publishing Company, 1987)

J.Satrio, Hukum Perikatan, Perikatan yang Lahir dari Perjanjian Buku I, PT. Citra Aditya Bakti, Bandung, 1995

Jack W. 'General aviation crash course: The First 15 Days", 39 Trial Lawyers of America 56, London, 2003,

Kelik Wardiono, 2005, Perjanjian Baku Klausula Eksonerasi Dan Konsumen: Sebuah Diskripsi Tentang Landasan Normatif, Doktrin, dan Praktiknya, Sukoharjo: Fakultas Hukum Universitas Muhammadiyah Sukoharjo

Mochtar Kusumaatmadja dan Etty R. Agoes, Pengantar Hukum Internasional, Bandung: PT. Alumni, 2003

Munir Fuady, Perbuatan Melawan Hukum, Cetakan 1, Citra Aditya Bakti, Bandung, 2002

P.N.H Simanjuntak, Pokok- Pokok Hukum Perdata Indonesia, Djambatan, Jakarta, 2009

Purwosutjipto, H.M.N. 1995. Pengertian Pokok Hukum Dagang Indonesia. Jilid 3. Jakarta: Djambatan.

Russel Davis, American Law of Products Liability", (New York: The Lawyers Cooperative Publishing Company, 1987)

Subekti, Aneka Perjanjian, Citra Aditya Bakti, Bandung, 1995

Subekti, Hukum Perjanjian, Intermasa, Jakarta, 2005

Sution Usman, dkk, Hukum Pengangkutan Indonesia Rineka Cipta, Jakarta, 1990

Zahry Vandawati, Hand Out Hukum Pengangkutan, Fakultas Hukum Universitas Airlangga, 2015

Sidharta, Hukum Perlindungan Konsumen Indonesia, Gramedia Widiasarana Indonesia, Jakarta, 2006

R. Soeroso, Perjanjian di Bawah Tangan (Pedoman Pembuatan dan Aplikasi Hukum), Alumni Bandung, Bandung, 1999 